\title{
Gambaran Reaksi Obat Yang Tidak Dikehendaki pada Pengobatan Tuberkulosis di Puskesmas Kabupaten " $X$ " Yogyakarta dan Hubungannya dengan Kepatuhan Minum Obat
}

\author{
Lucia Vita Inandha Dewi ${ }^{1,{ }^{*}}$, Lukman Hakim ${ }^{1}$, Sismindari ${ }^{1}$, Ngatidjan$^{2}$, Soni Prabowo Putra ${ }^{3}$ \\ ${ }^{1}$ Bagian Farmakologi, Fakultas Farmasi, Universitas Gadjah Mada, Yogyakarta \\ ${ }^{2}$ Bagian Farmakologi, Fakultas Kedokteran, Universitas Gadjah Mada, Yogyakarta \\ ${ }^{3}$ Bagian Farmakologi dan Farmasi Klinik, Fakultas Farmasi, Universitas Setia Budi Surakarta \\ *Email korespondensi: lucia.vita@yahoo.com
}

(Submit 15/03/2019, Revisi 05/09/2019, Diterima 20/12/2019)

\begin{abstract}
Abstrak
Pemantauan Reaksi Obat Tidak Dikehendaki (ROTD) perlu dilakukan pada pasien tuberkulosis untuk menjamin keamanan selama pengobatan dan meningkatkan kualitas hidup pasien mengingat banyaknya jenis obat yang digunakan dan durasi pengobatan yang cukup lama. Penelitian ini bertujuan untuk mengetahui gambaran ROTD yang terdiri dari : jenis, jumlah kejadian, dan waktu timbul, serta mencari hubungan antara terjadinya ROTD dengan kepatuhan minum obat. Penelitian ini merupakan penelitian observasional dengan rancangan studi kohort terhadap 33 pasien yang memenuhi kriteria inklusi, di beberapa puskesmas kabupaten X Yogyakarta, pada tahun 2017. Data ROTD didapat dari hasil wawancara dan pengisian lembar isian yang terdiri dari 12 macam pilihan ROTD mayor dan minor, data kepatuhan didapat dari pengisian kuesioner dengan metode Morisky Modification Adherence Scalle (MMAS)-8. Dari keseluruhan subyek yang diteliti 66,6 \% mengalami ROTD, 4,5\% mengalami lebih dari 5 jenis ROTD, 31,8\% mengalami 3 jenis, $27,27 \%$ mengalami 2 jenis, dan $31,8 \%$ mengalami 1 jenis. Dari 12 jenis ROTD yang diamati, terdapat 51 kejadian ROTD, dengan $11,76 \%$ kategori mayor yaitu gatal pada kulit dan gangguan penglihatan, serta $88,2 \%$ kategori minor. Gangguan pencernaan adalah jenis ROTD paling banyak dialami yaitu sebanyak $69 \%$ kejadian, sementara kram otot dan demam masing-masing sebesar $1,9 \%$. Dari $66,6 \%$ subyek yang mengalami ROTD tercatat kejadian timbulnya ROTD terbanyak terjadi pada 1 hingga 4 minggu setelah minum obat. Hasil uji chisquare antara kejadian ROTD dan tingkat kepatuhan menunjukkan tidak terdapat hubungan antara kejadian ROTD dengan tingkat kepatuhan, taraf sig 0,602 >0,05. Kejadian ROTD dialami oleh beberapa subyek penelitian terdiri dari ROTD mayor dan minor, namun tidak mempengaruhi tingkat kepatuhan minum obat pasien.
\end{abstract}

Kata kunci: Tuberkulosis, Obat Anti Tuberkulosis, Reaksi Obat, kepatuhan pengobatan, ROTD

\section{Outline}

- Pendahuluan

- Metode

- Hasil dan Pembahasan

- Kesimpulan

- Legal Responsibility

- Daftar Pustaka 


\section{Pendahuluan}

Pengobatan tuberkulosis saat ini menggunakan empat macam antituberkulosis yang terdiri dari Isoniazid $(H)$, Rifampisin $(R)$, Etambutol $(E)$, Pirazinamid $(Z)$ baik digunakan non KDT (Kombinasi Dosis Tetap) maupun dalam bentuk paket dosis tetap yang digunakan bersamaan dalam jangka waktu minimal 6 (enam) bulan untuk kategori 1, dan 8 bulan untuk kategori 2 dengan penambahan streptomisin injeksi, untuk pengobatan kategori 1 diberikan regimen $2 \mathrm{RHZE} / 4 \mathrm{H} 3 \mathrm{R} 3{ }^{1}$.

Beberapa kejadian melaporkan terjadinya Reaksi Obat Tidak Dikehendaki (ROTD) pada pasien, menurut literatur disebutkan bahwa obat antituberkulosis memiliki ROTD baik mayor maupun minor. Monitoring ROTD perlu dilakukan sebagi upaya meningkatkan asuhan kefarmasian sehingga pengobatan pasien dilakukan secara optimal, tepat, dan aman, seingga pasien sembuh dengan kualitas hidup yang baik, selain itu terjadinya ROTD juga dapat menyebabkan terputusnya pengobatan, sehingga menjadi faktor risiko terhadap timbulnya resistensi, gagal pengobatan, penurunan kualitas hidup hingga kematian. Prosedur monitoring ROTD merupakan bagian dari phaemacovigilance yang bisa dilakukan secara laporan spontan, laporan berdasar target, dan monitoring dengan mengikuti pengobatan.

\section{Metode}

\section{A. Bahan}

Form data ROTD, catatan medis pasien.

\section{B. Metode}

Penelitian ini adalah penelitian kohort studi yang dilakukan terhadap 33 pasien penderita tuberkulosis paru kategori 1yang sedang mendapat pengobatan tahap intensif, pengamatan dilakukan selama 6 (enam) bulan. Data diperoleh dengan prosedur wawancara dan pengisian form ROTD, keseluruhan prosedur dilakukan setelah ada persetujuan dari komite etik dari Fakultas Kedokteran UGM.

Kriteria inklusi yang ditetapkan adalah pasien tuberculosis paru kategori 1 yang sedang pengobatan dengan obat tuberculosis dalam bentuk kombinasi dosis tetap yang berusia 17 hingga 60 tahun, kriteria eksklusi dalam penelitian ini adalah pasien yang sedang pengobatan dengan obat selain obat tuberkulosis, menderita HIV, kehamilan.

\section{Hasil dan Pembahasan}

\section{A. Karateristik Pasien}

Karakteristik Responden, Jumlah pasien yang terlibat sebagai responden sejumlah 33 pasien, telah memenuhi kriteria inklusi, karakteristik pasien dapat dilihat pada tabel 1.

\section{B. Distribusi Pasien Berdasar Jumlah dan Jenis ROTD}

Dari 33 pasien yang terlibat dalam penelitian ini sebanyak 22 pasien mengalami ROTD, distribusi ditunjukkan pada gambar 1, sedangkan Dari 33 responden ada beberapa pasien yang megalami satu macam ROTD saja, teapi juga terdapat beberapa pasien yang mengalami lebih dari 1 macam ROTD, distribusi digambarkan pada gambar 2 . 
Tabel 1. Data Karakteristik Penderita Tuberkulosis Paru kategori 1

\begin{tabular}{|l|l|c|c|}
\hline No & Karakteristik & $\mathbf{f}$ & $\%$ \\
\hline 1. & $\begin{array}{l}\text { Jenis Kelamin } \\
\text { Laki-laki }\end{array}$ & 13 & 40 \\
$\quad \begin{array}{l}\text { Perempuan } \\
\text { Tingkat Pendidikan }\end{array}$ & 20 & 60 \\
SD & 4 & 12 \\
SMP & 10 & 30 \\
SMA & 15 & 45 \\
2. Parjana & 4 & 12 \\
\hline $\begin{array}{l}\text { Pekerjaan } \\
\text { wiraswasta }\end{array}$ & 8 & 24 \\
PNS/swasta & 2 & 6 \\
Petani & 7 & 21 \\
\hline Pedagang & 1 & 3 \\
Tidak bekerja & 15 & 45 \\
\hline
\end{tabular}

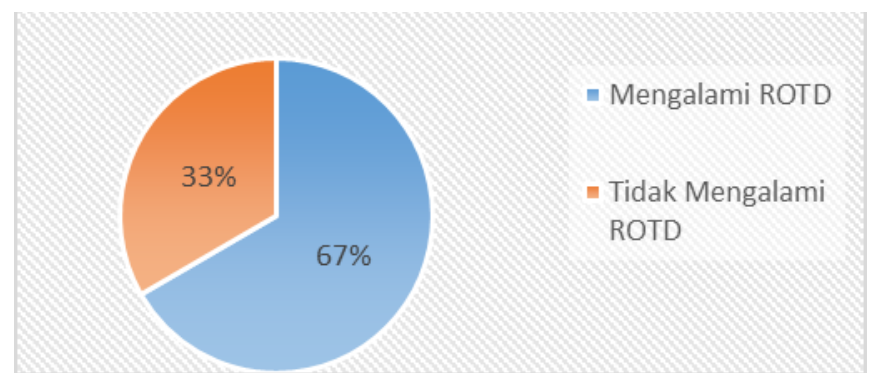

Gambar 1. Jumlah Pasien Yang Mengalami ROTD, $n=33$

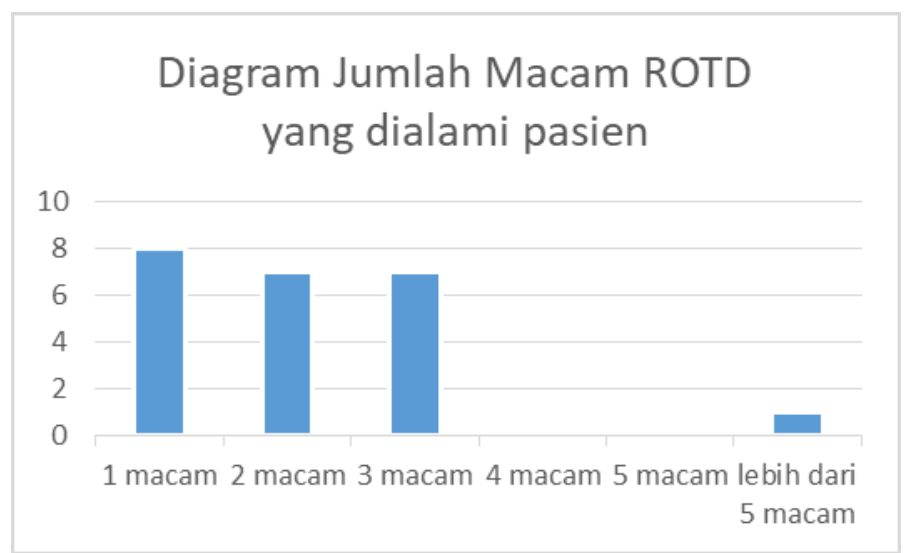

Gambar 2. Distribusi pasien berdasar jumlah ROTD yang dialami

Berdasarkan hasil penelitian didapatkan hasil bahwa reaksi obat yang tidak dikehendaki (ROTD) terjadi pada 22 pasien (67\%) dari total sampel sebanyak 33 pasien, dengan distribusi terbesar adalah gangguan gastrointestinal sebanyak 15 kejadian dari 33 pasien dengan persentase sebesar $45 \%$, sejalan dengan beberapa penelitian sebelumnya yang dilakukan oleh Venkateswarlu et al. dari 119 pasien terdapat $45 \%$ mengalami gangguan gastrointestinal, ROTD ini merupakan kejadian paling besar diantara jenis ROTD yang lain². Penelitian oleh Anusha N, (2014) juga menyebutkan jenis ROTD terbesar dari 40 pasien pengobatan tuberculosis adalah gangguan gastrointestinal 77\%, Gangguan gastrointestinal dapat berupa mual, muntah, dan sakit perut, dapat disebabkan oleh Rifampisin, Isoniazid maupun pirazinamid ${ }^{2,8}$ Gangguan gastrointestinal dapat bersifat simptomatik ringan yang dapat diatasi dengan 
pengaturan pola minum obat, namun dapat juga dapat membahayakan, kaena gejala tersebut bisa merupakan gejala awal yang menandai gangguan fungsi hepar ${ }^{6}$ sehingga monitoring terhadap ROTD ini perlu dilakukan untuk meningkatkan kualitas hidup pasien. Distribusi jenis dan jumlah kejadian ROTD dapat dilihat pada tabel 2.

Tabel 2. Distribusi Jenis dan jumlah kejadian ROTD

\begin{tabular}{|c|c|c|c|c|}
\hline No. & Jenis ROTD & $\begin{array}{l}\text { Angka } \\
\text { kejadian }\end{array}$ & $\begin{array}{l}\text { Persentase (\%) dari total } \\
\text { sampel yang mengalami } \\
\text { ROTD ( } n=22)\end{array}$ & $\begin{array}{c}\text { Persentase (\%) } \\
\text { Dari total sampel } \\
(n=33)\end{array}$ \\
\hline 1. & Gangguan Gastrointestinal & 15 & 68 & 45 \\
\hline 2. & Badan terasa lemah & 2 & 9 & 6 \\
\hline 4. & Demam & 1 & 4 & 3 \\
\hline 5. & Gatal & 3 & 13 & 9 \\
\hline 6. & Nyeri kepala & 7 & 32 & 21 \\
\hline 7 & Gangguan penglihatan & 3 & 13 & 9 \\
\hline 9. & Nyeri sendi & 5 & 23 & 15 \\
\hline 10. & Kesemutan & 5 & 23 & 15 \\
\hline 11. & Kram & 10 & 45 & 30 \\
\hline 12. & Kelemahan anggota gerak & 0 & 0 & 0 \\
\hline 13. & Gangguan hepar & 0 & 0 & 0 \\
\hline & Total kejadian & 51 & & \\
\hline
\end{tabular}

ROTD ke dua yang paling banyak dialami pasien berupa rasa nyeri baik pada persendian, kepala, kram pada kaki, maupun terjadinya kesemutan, gejala tersebut dapat merupakan gejala awal timbulnya neuritis ${ }^{4}$, yang dapat disebabkan oleh obat Isoniazid ${ }^{5}$, dan berkaitan dengan terjadinya interaksi antara isoniazid dengan vitamin B6 sehingga terjadi penurunan jumlah vitamin B6 yang diperlukan oleh system syaraf dalam tubuh ${ }^{7}$.Pada kasus ini, meskipun gejala gastrointestinal yang terjadi dapat merupakan bagian dari gejala awal gangguan hepar namun kejadian (hepatotoksisitas) yang dikonfirmasi dengan tanda klinis dan pemeriksaan laboratorium berupa peningkatan AST/ALT tidak ditemukan dalam kasus ini. ROTD berupa ruam kulit dan gatal terjadi pada 3 kasus dari 33 pasien, meskipun kasus ini jarang terjadi namun termasuk dalam ROTD mayor, pirazinamid adalah salah satu obat yang dapat menyebabkan gangguan kulit berupa exanthema dan berkaitan dengan mekanisme alergi ${ }^{8}$.

\section{Gambaran Tingkat Kepatuhan Pasien}

Kepatuhan pengobatan pasien diukur menggunakan metode Morinsky Medication Adherence Scale (MMAS-8), seperti pada tabel 3.

Tabel 3. Gambaran tingkat kepatuhan pasien penderita tuberkulosis 2 kategori

\begin{tabular}{|c|c|c|c|c|}
\hline Variabel & Skor & Kategori & Jumlah & Persentase (\%) \\
\hline Kepatuhan & $<6$ & Tidak Patuh & 2 & $6,3 \%$ \\
\hline & $>6$ & Patuh & 31 & $93,8 \%$ \\
\hline
\end{tabular}

Kepatuhan pengobatan merupakan hal yang perlu dimonitor karena akan terkait dengan kesembuhan pasien, salah satu penelitian oleh Samsurian, 2010 menyatakan adanya faktor risiko default dengan timbulnya ROTD9, namun pada penelitian ini berdasar uji chi square tidak ditemukan adanya pengaruh kejadian ROTD dengan 
tingkat kepatuhan pasien dengan taraf sig $>0,005$ hal ini sejalan dengan penelitian yang dilakukan oleh Rahmi dkk pada tahun $2017^{10}$.

\section{Kesimpulan}

Reaksi Obat Tidak Dikehendaki pada pengobatan tuberculosis dapat terjadi pada pasien, meskipun tidak berpengaruh terhadap kepatuhan pengobatan, namun monitoring terhadap ROTD tetap diperlukan untuk tercapainya pengobatan yang aman dan berkualitas bagi pasien.

\section{Legal Responsibility}

Penelitian ini telah mendapat approval dari Komite Etik Fakultas Kedokteran Universitas Gadjah Mada dengan nomer surat : KE/FK/1334/EC/2015

\section{Daftar Pustaka}

1. Anonim, Pharmaceutical Care Untuk Penyakit Tuberkulosis, Direktorat Bina Farmasi Komunitas dan Klinik, Dirjen Bina Kefarmasian dan Alat Kesehatan Departemen Kesehatan RI, 2005, 26-27

2. K.Venkateswarlu,Keerti Tiwari, E.Mamatha, SaiVivek, P.Shravan. Study Of Adverse Drug Reactions in Tuberculosis Patients. J Pharma Res, 2017, 6(Suppl 2):61-65

3. Adverse drug reactions monitoring among TB patients on anti-tubercular drugs under RNTCP in Pondicherry.2014 International Journal of Advanced Research,Volume 2, Issue 12, 165-173

4. US Department of Health And Human Services. Peripheral Neuropathy, National Institute of Neurological Disorders and Stroke.2014. NIH Publication No 15-4853,36

5. Mark Stettner, Daniela Steinberger, Christian J. Hartmann, Tatjana Pabst, Lidija Konta, Hans Peter Hartung \& Bernd C. Kieseier. Isoniazid-induced polyneuropathy in a tuberculosis patient - implication for individual risk stratification with genotyping? 2014.Brain and Behavior, published by Wiley Periodicals, Inc.doi: 10.1002/brb3.326 (2 of 4)

6. Jussi J. Saukkonen, David L. Cohn, Robert M. Jasmer, Steven Schenker, John A. Jereb, Charles M. Nolan et al. An Official ATS Statement: Hepatotoxicity of Antituberculosis Therapy. Am J Respir Crit Care Med Vol 174. pp 935-952, 2006 DOI: 10.1164/rccm.200510-1666ST Tspilnternet address: www.atsjournals.org

7. Nisar, SW Watkin,RC Bucknall, and RA Agnew,Exacerbation of isoniazid induced peripheral neuropathy by pyridoxine. Thorax. BMJ Publishing Group,1990 May; 45(5): 419-420

8. Khalid Umer Khayyam, Faisal Imam, Manju Sharma, K.K Pillai, D Behera, Pirazinamid Inducen Macopapular Rash, Indian Journal of dermatology, 2010 OctDec; 55(4): 384-386

9. Samsu Rian. Pengaruh Efek Samping Obat Anti Tuberkulosis Terhadap Kejadian Default di RS Islam Pondok Kopi Jakarta Timur Januari 2008-Mei , 2010.Skripsi

10. Nitari Rahmi, Irvan Medison, Ifdelia Suryadi, Hubungan Tingkat Kepatuhan Penderita Tuberkulosis Paru dengan Perilaku Kesehatan, Efek Samping OAT dan Peran PMO pada Pengobatan Fase Intensif di Puskesmas Seberang Padang, September 2012-Januari 2013, Jurnal Kesehatan Andalas, 2017:6(2) 